\title{
OLD WAYS IN THE \\ KOLAR GOLD FIELD
}

\author{
P.T. Craddock \\ Research Laboratory, \\ The British Museum, \\ London WC1B 3DG
}

Present workings at India's Kolar gold Field are well over

3000 metres deep, surpassed only by some gold mines in

South Africa. But the history of gold mining in the region goes back to the early second millenium $B C$.

I n December 1990 a small team from the British Museum and the Peak District Mining Museum, Derbyshire, were invited by Bharat Mines Co. in India to carry out a preliminary survey of the remains of early mining activity and to assess the archaeological potential at the Kolar Gold Field (KGF), which lies about $50 \mathrm{~km}$ east of Bangalore in central south India in the state of Karnataka.

The modern history of the KGF began just over a century ago when the British mining company, John Taylor, took over management and development of the mines. Under their expert guidance the mines rapidly progressed as the most modern methods and machinery were introduced. Electric power was installed in the 1920 s, long before it appeared elsewhere in southern India, and in the 1930s it was the mine's boast that one could phone John Taylor's London office direct from over a kilometre underground.
A feature of these mines has always been their great depth, and the present workings penetrate the earth's surface by well over three kilometres, surpassed only by some gold mines in South Africa. Such enormous depths require special equipment and the mines still have the world's largest winding drum, which was made in Manchester, England over half a century ago. Indeed much of the machinery installed by the Taylors still functions although between 50 and 100 years old, a tribute both to the original manufacturers and to continuing excellent maintenance by the present staff, now part of the Bharat Mine group, a government of India enterprise.

The industrial archaeology of the mines deserves study and preservation in its own right, but the KGF have a history that extends way back before any European involvement. These mines, in effect, provided great wealth to the rulers of southern India in medieval 

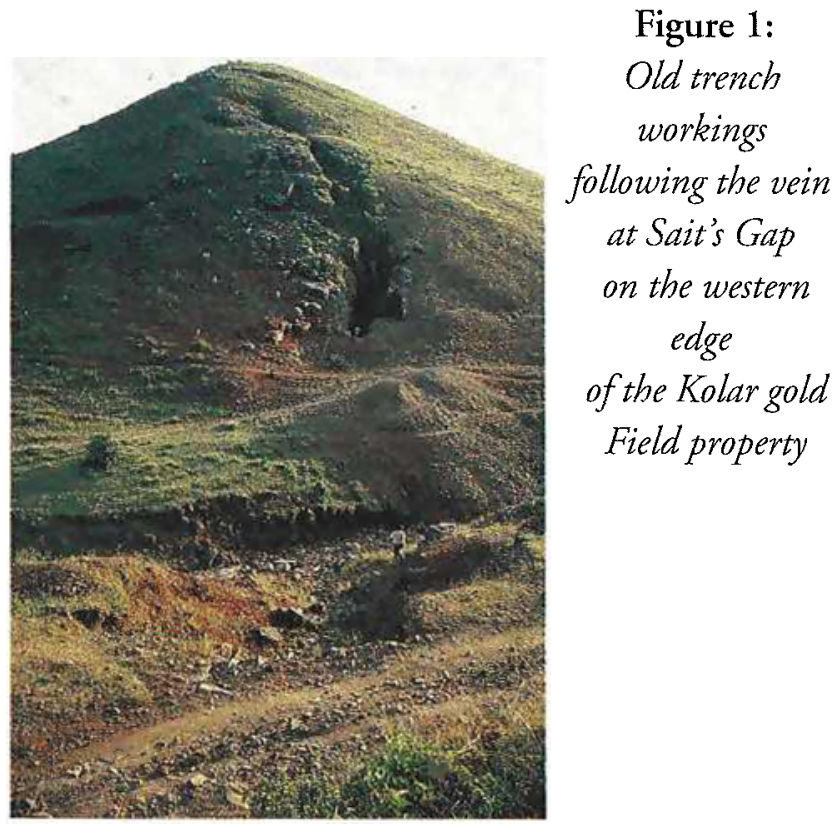

times and much earlier, as suggested by carbon dates of $1890 \pm 70 \mathrm{BC}$ and $1810 \pm 70$ for timbers found in old workings at a depth of eighty metres underground in the Oakley shaft at the Hutti gold field, which lies about $100 \mathrm{~km}$ of Kolar [1].

The deposits are rather unusual in that almost all the ore is in primary quartzite veins with little or no secondary deposits. Thus, the mines are nearly all in hard rock, and as the veins dip very steeply even the early workings can be at depth. At Kolar the early workings have been intercepted at up to thirty metres below ground, and at Hutti workings worked by the traditional method of firesetting have been encountered over 200 metres below ground. Most of visible evidence is now at ground level, where old trench mines run along the tops of the veins at Kolar for many kilometres (Figures $1 \& 2$ ). The depth of these is difficult to assess, but sometimes they are interspersed with quite deep shafts (Figure 3). The

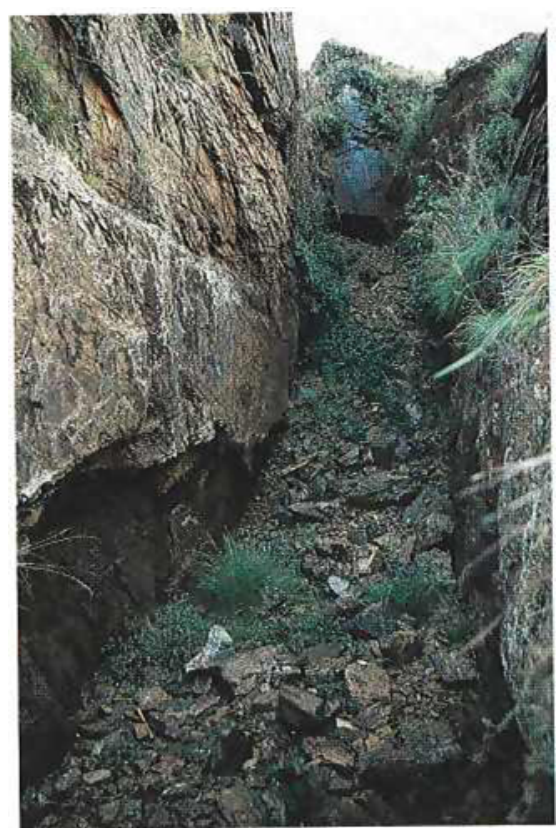

Figure 2:

Detail of

the old trench

working

at

Sait's Gap

quartzitic vein material was set in a country rock of metamorphosed basalts, all hard material that had to be shattered by firesetting before it could be satisfactorily mined (Figure 4). The ore was usually crushed on site to release the gold, and many pebbles used as hammer stones are to be found all over the workings together with the hollows worn in the rocks used as anvils in the crushing operations (Figure 5).

As these are primary deposits, the gold is very finely dispersed and in the recent past the crushed ore was

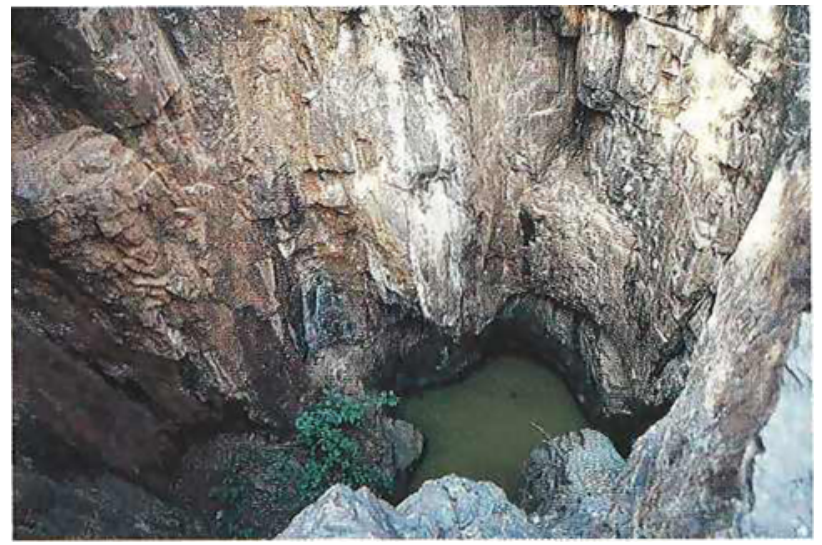

Figure 3:

Complex series of early shafts at Guvvalagunta, about $15 \mathrm{~km}$ south of the main Kolar mines, creating a deep mine treated with mercury to collect the gold by amalgamation, and this process is said to be still practised by some small-scale private operators at the Gadag gold field, which lies about fifty $\mathrm{km}$ north of Kolar. The Bharat company use vanning tables and cyanide treatment in the modern plant. Side by side with this at Kolar there is much more primitive, and quite unofficial goldworking! 


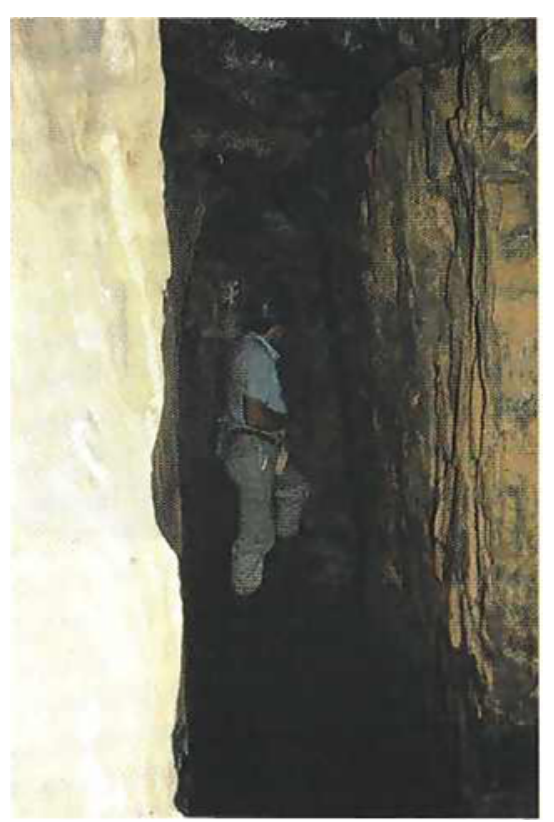

Figure 4:

Early gallery

at Chigargunta,

about $35 \mathrm{~km}$

south of the main

Kolar mines. The

very smooth pro-

file of the meta-

morphised basalt

rock face

is quite typical

of firesetting

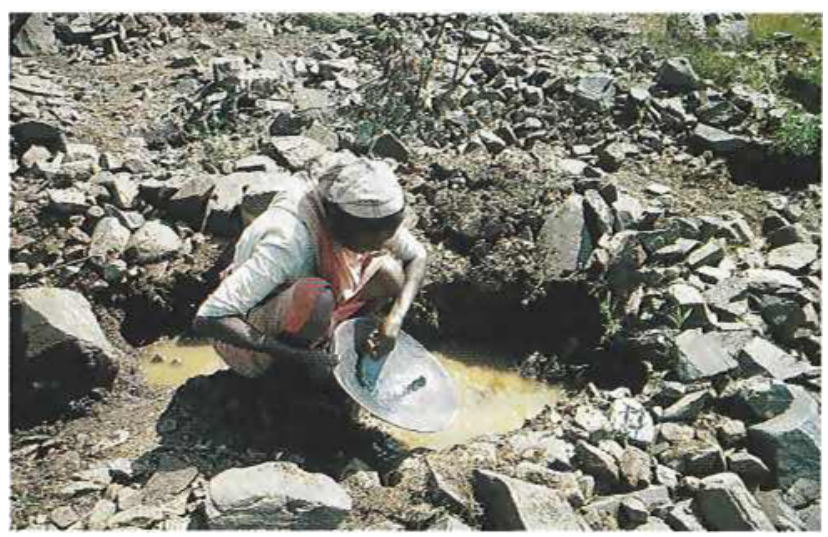

Figure 6:

Local women panning for gold,

Kolar Gold Field,

December 1990

On one of our surveys out at the far end of the mine property, well away from any modern working, we came across some local women panning for gold in the alluvium running from the old mine tips (Figures 6,7 \& 8). After overcoming their initial fright they allowed us to photograph them and told us how they won the gold. Small holes are dug in promising silt (Figure 9), and the larger lumps of quartz are crushed (Figure 10). The material is then washed in the iron pans, the lighter alluvium being carried over the sides, leaving behind

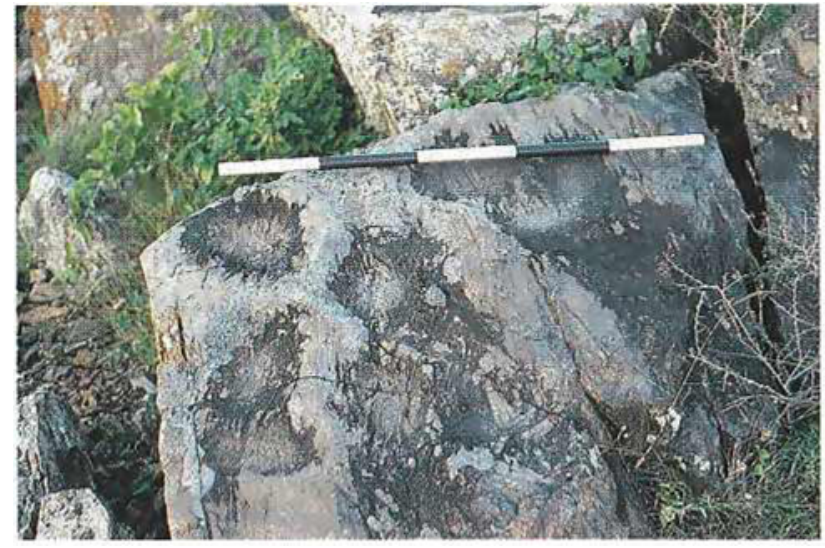

Figure 5:

Rock face adjacent to the trench mines at Sait's Gap covered in small depressions where it has been used as an anvil in the crushing operations

Figure 7:

Local women panning for gold

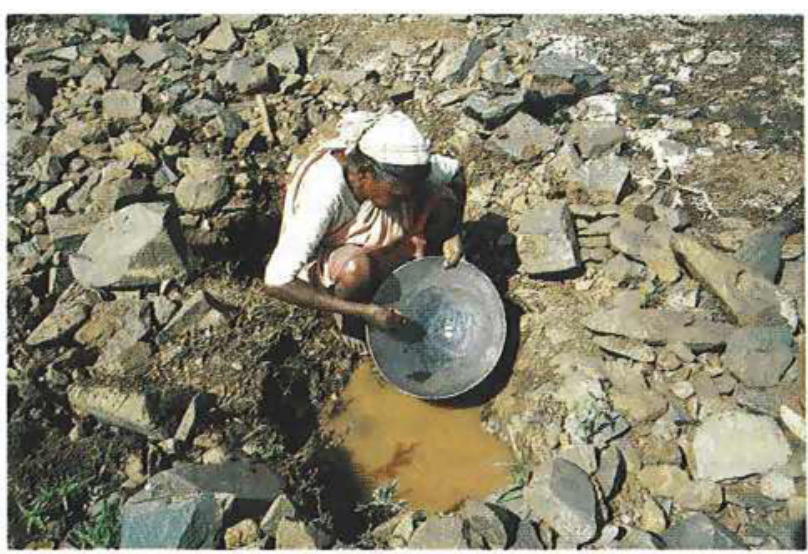

the denser gold, sand of magnetite and pyrite with more gold adhering (Figure 11). There are said to be about one hundred people engaged in this work, although certainly not on a full time basis. The women we spoke to said that they reckoned to earn between ten and twenty rupees per day, which compares with a wage of fifteen rupees a day for women agricultural labourers (a miner in the Bharat mines would earn about 1500 rupees per month; there were about 35 rupees to the pound sterling at the time of our visit). 


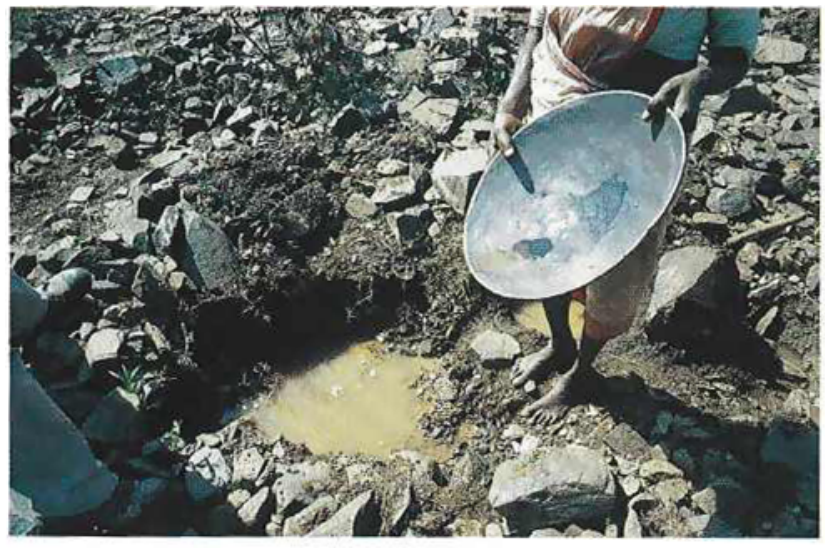

Figure 9:

Residue of gold and black gold rich pyritic sands retained after washing

Middlemen bought the gold concentrates from the women, paying one hundred rupees per gram, and they in turn sold it to the local jeweller who released the gold by treatment with aqua regia, in the time-honoured fashion.

Panning must be one of the very earliest methods of winning and separating metals, but the operation will have left very little evidence for the mining archaeologist to study. The small ephemeral holes dug in the soft gravels and silts will have filled almost immediately, and no tools will have survived apart from the

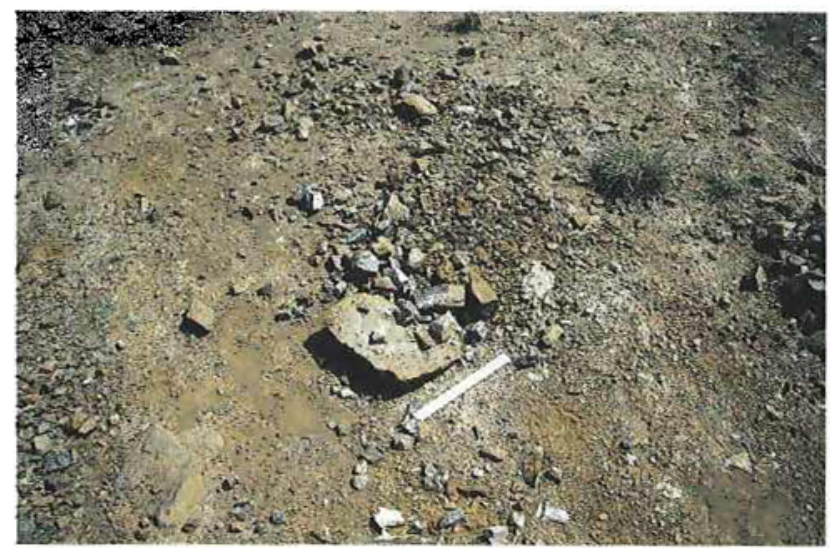

Figure 11:

Area where gold-bearing rock

has been crushed using

the large rock as an anvil

(scale is $30 \mathrm{~cm}$ )

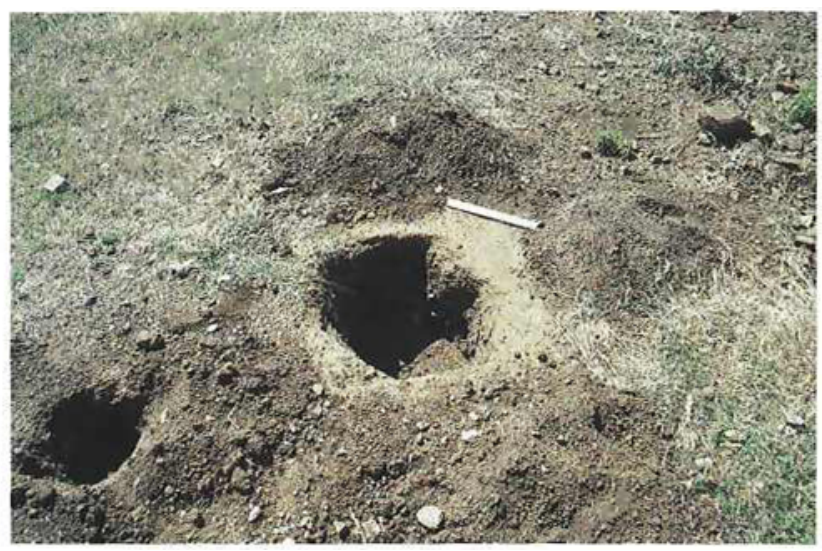

Figure 10:

Small holes dug by the panners

to get the gold bearing rocks

(scale is $30 \mathrm{~cm}$ )

hammerstones and crushing sites such as we found all over the mined area. Thus, it was especially valuable to come across people still practising this simple technology. Much of the gold we now admire in ancient Indian jewellery will have been recovered in operations very similar to those we recorded at Kolar.

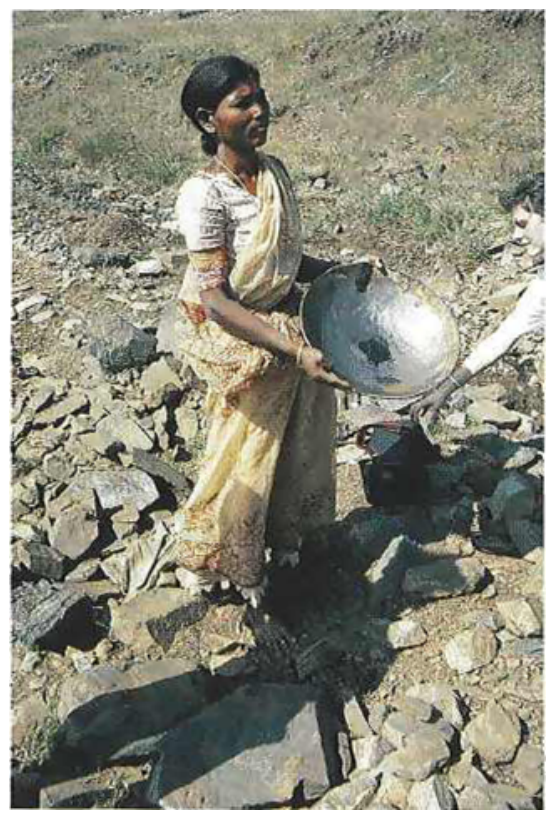

Figure 8:

Local women panning for gold 


\section{ACKNOWLEDGEMENT}

We are very grateful to $\mathrm{Mr}$. Chetty, general production manager and to Mr. K. Balan, Chief surveyor, and indeed to all the staff of the Bharat Mine company for inviting us and making our visit so enjoyable. We are especially grateful to Mr. C.V. Seshadri, senior geologist and his colleagues who acted as our guides. Their enthusiasm and detailed knowledge of all aspects of the geology and workings of the mines, as well as of the local Kanada language, contributed enormously to the success of the visit and based on this we now hope to return to work with them to elucidate more of the history of this fascinating gold mine.

\section{REFERENCE}

[1] Allchin, F.R.A., 'Gold mining in ancient India', Journal of the Economic and Social History of India 1962, 5(2), 195-211. 